IZA DP No. 10300

The Intergenerational Transmission of Human Capital and Earnings in Contemporary Russia

Gleb V. Borisov

Christopher A. Pissarides

October 2016 


\title{
The Intergenerational Transmission of Human Capital and Earnings in Contemporary Russia
}

\author{
Gleb V. Borisov \\ St. Petersburg State University \\ Christopher A. Pissarides \\ London School of Economics and IZA
}

Discussion Paper No. 10300

October 2016

\author{
IZA \\ P.O. Box 7240 \\ 53072 Bonn \\ Germany \\ Phone: +49-228-3894-0 \\ Fax: +49-228-3894-180 \\ E-mail: iza@iza.org
}

Any opinions expressed here are those of the author(s) and not those of IZA. Research published in this series may include views on policy, but the institute itself takes no institutional policy positions. The IZA research network is committed to the IZA Guiding Principles of Research Integrity.

The Institute for the Study of Labor (IZA) in Bonn is a local and virtual international research center and a place of communication between science, politics and business. IZA is an independent nonprofit organization supported by Deutsche Post Foundation. The center is associated with the University of Bonn and offers a stimulating research environment through its international network, workshops and conferences, data service, project support, research visits and doctoral program. IZA engages in (i) original and internationally competitive research in all fields of labor economics, (ii) development of policy concepts, and (iii) dissemination of research results and concepts to the interested public.

IZA Discussion Papers often represent preliminary work and are circulated to encourage discussion. Citation of such a paper should account for its provisional character. A revised version may be available directly from the author. 


\section{ABSTRACT}

\section{The Intergenerational Transmission of Human Capital and Earnings in Contemporary Russia*}

We make use of longitudinal data for the Russian economy over 1994-2013 to obtain earnings and education information about parents and children. We estimate the intergenerational transmission of educational attainment and earning capacity and find high intergenerational correlation of earnings for both sons and daughters independently of educational qualifications. We attribute them to the impact of informal networks. We also find high correlation of educational qualifications but with critical variations due to labour market conditions. At the time of transition around 1990 children's educational attainment fell well below parents but recovered a decade later when the economy was booming.

JEL Classification: J21, J23, J24, J62, O15

Keywords: human capital, intergenerational education mobility, intergenerational earnings elasticity, Russia

Corresponding author:

Christopher A. Pissarides

Department of Economics

London School of Economics

Houghton Street

WC2A 2AE

London

United Kingdom

E-mail: c.pissarides@Ise.ac.uk

\footnotetext{
* This paper was written at the Growth Laboratory of the St.-Petersburg State University. We are grateful to Otar Marganiya, the Dean of the Business School, for his support and to the other members of the Laboratory for helpful interactions.
} 


\section{Introduction}

This paper makes use of panel data to study the intergenerational transmission of human capital and earnings in post-reform Russia. Our approach follows that of Becker and Tomes (1979), who explain the reasons for the persistence of between-family earnings differentials in terms of educational investments. They argue that higher-income families endow their children with more human capital, and so the children become higher-earning individuals themselves. Our main findings differ with respect to the main transmission mechanism, in that we find that the preservation of higher earnings within families takes place through other informal channels and not through larger educational investments by higher-income families. We find that highly educated parents endow their children with more education, and so both parents and children earn higher incomes; but controlling for education, higher earning parents do not endow their children with more education and yet their children do end up being high earners themselves. Our data source is the Russian Longitudinal Monitoring Survey (RLMS), which contains a wealth of information about individuals and their families. ${ }^{1}$

Our study takes place in the volatile background of post-reform Russia and we are able to identify the impact of macro fluctuations on human capital and earnings. In the last three decades Russia experienced the collapse of the planned economy of the previous sixty years, a subsequent deep structural and financial crisis that lasted until the end of the 1990s and a rapid growth of free-market institutions and practices during the 2000s. These transitions were accompanied by dramatic fluctuations in the demand for skilled labour by firms and government and by large changes in the quantity and type of education taken up by young people. Our estimates of the educational attainment of different cohorts of young people in different macro environments allows us to reach some conclusions about the human capital

\footnotetext{
${ }^{1}$ The Russia Longitudinal Monitoring survey, RLMS-HSE is conducted by the National Research University "Higher School of Economics" and the ZAO "Demoscope," together with the Carolina Population Center, University of North Carolina at Chapel Hill and the Institute of Sociology RAS. For more details see http://www.cpc.unc.edu/projects/rlmshse and http://www.hse.ru/org/hse/rlms.
} 
cost of the transition to a market economy. We find a substantial impact of recession on the demand for higher education, which can potentially give rise to large long-term costs associated with the transition.

Previous work with the RLMS has been mainly concerned with the impact of transition on the structure of employment and the returns to human capital. Berger et al. (2001) find limited training outside the worker's own field when compared with the United States, which, consistent with our findings, would limit income mobility (see also Clerk, 2003)). Gorodnichenko and Sabirianova Peter (2005) estimate the returns to schooling at different quantiles of the wage distribution and find substantial lower returns at the top of the distribution. Maltzeva (2009) finds that the return to job mobility is small for workers over 25, so job mobility is not a source of higher returns to education. These claims are consistent with the finding in this paper that high earners pass the ability to earn high wages to their children independently of human capital acquisition or progression up the jobs ladder. ${ }^{2}$

We use the RLMS for the maximum currently available period, 1994-2013, to extract earnings and other characteristics data for fathers or mothers and their children. We then estimate the factors that explain the educational attainment and earnings level of children in terms of a variety of characteristics, including parents' education and earnings. Section 2 discusses our empirical modelling approach. Section 3 describes the data and explains how we extract the sample of parents and children that we use in our estimation. Section 4 reports and discusses the estimation results. Section 5 makes use of the estimation results to derive transition probabilities across educational groups for men and women and finally, the concluding section, gathers together the most important findings and draws out some policy conclusions. Detailed reporting of estimation results is collected in several Appendix tables.

\footnotetext{
${ }^{2}$ For more studies on income mobility and the returns to human capital see Lukiyanova and Oshchepkov (2012), Gimpelson and Kapeliushnikov (2007) and Lukiyanova (2010).
} 


\section{Modelling approach}

Following Becker and Tomes (1979), we assume that a person's human capital depends on investments made by parents. The rate of return on human capital (earnings) depends on family background, the person's ability, and luck. Family background influences the return to human capital through a variety of mechanisms, including information and ability to take advantage of educational opportunities, norms within the family that influence motivation and the work rate, social networks and wealth. The parents' willingness to invest in their children's human capital and the common family background lead to a correlation between the parents' permanent earnings and their children's permanent earnings, measured here by the "intergenerational earnings elasticity":

$$
\ln Y_{i}^{C}=a_{0}+a_{1} \ln Y_{i}^{P}+\mathbf{A} \mathbf{X}_{\mathbf{i}}+e_{i 1}
$$

where $\ln Y_{i}^{C}$ and $\ln Y_{i}^{P}$ respectively are the logs of permanent earnings of children and parents, $a_{1}$ is the intergenerational earnings elasticity, $\mathbf{X}_{\mathbf{i}}$ is a vector of environmental characteristics, such as region and the demographics of the local area, $\mathbf{A}$ is a vector of coefficients and $e_{i 1}$ is an error term reflecting the effect of other factors such as luck.

Permanent earnings are the most appropriate measure of earning capacity, because current earnings depend on such time-varying factors as age and hours worked that contaminate the connection between parents' and children's earnings capacity. Regressing current earnings of children and parents on time-varying factors and using the residuals as an estimate of permanent earnings is a straightforward approach to obtaining permanent earnings from observed current earnings (see, e.g., Dearden et al., 1997).

Becker and Tomes (1979) interpret the elasticity $a_{1}$ as the propensity of parents to invest in their children's human capital. But earnings are influenced by a large number of factors beyond formal investments in human capital. A parent with high earnings might be more likely to invest in his or her children's education but a parent might also have access to professional or social networks that automatically become available to the children. We 
distinguish between the two, formal education and unobserved other influences on earnings, by introducing the educational attainments of parents and children in the regression.

Other omitted variables that can bias the estimate of $a_{1}$ are personal characteristics that are correlated with both parents' and children's earnings. We generalize our regression estimate by expanding the set of independent variables with a number of personal characteristics to account for as many influences on children's earnings as possible. The coefficient $a_{1}$ picks up connections between parents' and children's earnings that are unaccounted for by the usual set of explanatory variables in earnings regressions.

We make two other adjustments to reduce measurement errors, which, as Solon (1992) noted, bias the OLS estimate of $a_{1}$ downward. First, we average earnings over a five-year period to get rid of any impact from temporary shocks that are not completely netted out by our estimation procedure. Second, even when adjusted for the effect of age, earnings of younger individuals who are at the beginning of their careers are a poor proxy for their lifetime earning capacity. We drop very young respondents and include only individuals with some work experience in our sample.

In light of this discussion the estimated equation is the following modified form of equation (1):

$$
\ln Y_{i}^{C}=b_{0}+b_{1} \ln Y_{i}^{P}+b_{2} E_{i}^{P}+b_{3} E_{i}^{C}+\mathbf{B Z}_{\mathbf{i}}+e_{i 2}
$$

where $E_{i}^{P}$ and $E_{i}^{C}$ are the educational attainment of a parent and child respectively and $\mathbf{Z}_{\mathbf{i}}$ is a vector of variables that includes environmental variables and demographic characteristics of children, such as ethnic origin, marital status and gender. In equation (2), the investment of parents in their children's education is captured by the children's educational attainment, $E_{i}^{C}$. The demographic and personal characteristics in $\mathbf{Z}_{\mathbf{i}}$ capture other observed influences on earnings that are unrelated to parents' status, so the coefficient $b_{1}$ on parents' earnings now captures the effect of unobserved variables correlated with parents' earnings, the main ones being the family social and professional networks built up by parents due to their income status. Similar 
influences that are due to the parents' educational attainment are picked up by the estimated $b_{2}$, isolating as much as possible the impact of earningsrelated influences in $b_{1}$.

We exclude children's occupation from equation (2) because of data limitations with our sample, as the sample size that includes both parents' income and children's occupation is very small. Since the main problem with the exclusion of own occupation is that the return on own education might be biased, we estimate also an equation that includes own occupation but drops parents' income in order to increase sample size,

$$
\ln Y_{i}^{C}=c_{0}+c_{1} E_{i}^{P}+c_{2} E_{i}^{C}+c_{3} O C C_{i}+\mathbf{C Z}_{\mathbf{i}}+e_{i 3}
$$

where $O C C_{i}$ is children's occupation. The objective is to compare the estimated returns to education in equations (2) and (3).

In addition to the equations for the transmission of earning capacity, we estimate the following equations for the intergenerational transmission of educational attainment

$$
\begin{gathered}
E_{i}^{C}=d_{0}+d_{1} E_{i}^{P}+\mathbf{D Q}_{\mathbf{i}}+e_{i 4}, \\
E_{i}^{C}=f_{0}+f_{1} E_{i}^{P}+f_{2} \ln Y_{i}^{P}+\mathbf{F} \mathbf{Q}_{\mathbf{i}}+e_{i 5} .
\end{gathered}
$$

where $\mathbf{Q}_{\mathbf{i}}$ is a vector of variables that includes those in $\mathbf{Z}_{\mathbf{i}}$ and some others (the birth cohort, the total number of family's members and the number of children aged 3 or below and between 3 and 17, that might influence the educational investment of parents in their children). The birth cohort is included to capture the effect of general macroeconomic conditions on the parents' decision to invest in their children's education. The parents' financial capacity to invest in their children's education is captured by the coefficient $f_{2}$, whereas the coefficient on parents' educational attainment, $d_{1}$ or $f_{1}$, captures the effect of family values, background and access to information that influence children's educational attainment independently of how much command the family has over financial resources. We estimate separately equations (4) and (5) because of limitations in our sample. The sample 
that does not include parents' income is much larger.

The full effect of parents' educational attainment and income on children's earnings is obtained when $E_{i}^{C}$ is substituted from equation (5) into equation (2) to obtain the coefficient $b_{2}+b_{3} f_{1}$ on parents' education and $b_{1}+b_{3} f_{2}$ on parents' permanent income.

Estimates in the literature show a positive and significant coefficient of intergenerational transmission of permanent earnings, $a_{1}$, practically in all countries for which evidence is available (see Solon, 1999; D'Addio, 2007). Cross-country comparison of intergenerational income elasticities based on various measures of earnings for pairs of fathers and sons suggests that the transmission is highest in the United Kingdom, Italy, the United States and France. In these countries at least $40 \%$ of the economic advantage that high-earning parents have over low-earning parents is passed on to the next generation. In contrast, intergenerational transmission is comparatively low in the Nordic countries, Australia and Canada, with less than $20 \%$ of the earnings advantage passed from parent to offspring.

National peculiarities as to the financing of education, the degree of openness of the labour market and parents' preferences for investing in the human capital of the next generation are factors cited for the international differences in the intergenerational income elasticity. Solon (1999) describes a society with a very high degree of transmission as a "cast" society, where children inherit their parents' position in the wage distribution.

Empirical estimates of equations (2) and (5) for several countries show that parents' education mainly influences children's earnings through educational attainment (i.e., via $b_{3} f_{1}$ ). But in some countries (the United Kingdom, Spain, Italy, Netherlands, Luxembourg and Ireland) the direct linkage via $b_{2}$ is more important. In most countries the direct effect of father's education, measured by $b_{2}$, is not statistically significant in determining their children's wages, once the children's educational attainment is taken into account (Causa et al., 2009). As for earnings transmission, there is evidence that there is both direct transmission, through the coefficient $b_{1}$, and indirect, through the impact of parents' income on the child's educational attainment, measured by the coefficient $b_{3} f_{2}$ (D' Addio, 2007, Chevalier et al., 2013) 
When one estimates equations (1) and (2) by OLS on the entire sample, the effect of explanatory variables is identical across the entire distribution of the dependent variable. Becker and Tomes (1979) argue that low-earning parents are constrained in their ability to finance the education of their children, whose earnings as a result are below the earnings of children with the same ability from unconstrained families. Following this argument, Bratberg et al. (2005) used a quantile regression to explore the idea that the impact of the explanatory variables is different at different ranges of the distribution of the dependent variable (the log of permanent earnings). We test this hypothesis by also estimating quantile regressions.

\section{Data and choice of variables}

The Russia Longitudinal Monitoring Survey (RLMS) is the primary source of data used in this paper. The RLMS is an annual multi-wave data set of a representative sample of more than 10,000 individuals that started in 1992. Because the survey was redesigned in 1994 and lost consistency with the previous two waves, we use data for the 18 years 1994-2013, 2013 being the latest available year at the time of writing.

The RLMS started as an unbalanced panel of 4,000 household addresses. New households are added in two different ways. First, children who leave the parents' original address are followed up and if they remain in the same local area their new address is added to the survey. If they leave the local area they are dropped from the survey. Second, a family that moves within the same local area is traced and its new address is added to the survey; the original household address is not removed from the survey and the new resident is added to the survey. Attrition is due to natural causes, refusal to continue participation and moving to another area, as no effort is made to trace respondents who have left the original locality. On average $8 \%$ of respondents were lost each year from 1994 to 2009, before the sample size changed more fundamentally in 2010. In that year the sample was increased by about 2,000 addresses, in order to improve its representativeness across the regions of the country. The sampled population increased from 13,991 individuals in 2009 to 21,343 in 2010 . 
Parents' and children's personal characteristics can be matched from household data when children still belong to the household, whereas income and educational attainments are matched by combining parents' responses with those of children who have left the household but remained within the same local area. When children leave home and move outside the local area the link is lost, as those children are dropped from the survey. Although this feature of our sample probably puts more weight on children who are born in the large cities, we have enough observations from outside the cities to obtain reliable estimates.

There is a large number of useable characteristics in the survey and a number of different measures of income. Income measures include wages and salaries at a primary place of work, earnings elsewhere, wages owed by employers but not yet paid, earnings in-kind and total income from all sources (including e.g., income from capital). We consider wages and salaries at the primary place of work to be the most appropriate measure for our research, as we are looking for estimates of permanent income (see also the discussion below in the context of the estimated equations). In line with this decision, we also use the reported hours of work in the primary place of work as our measure of working time.

The survey includes information on years of schooling and academic degrees obtained. Educational standards in the Soviet Union and then in Russia have changed several times, so to obtain the same degree in different periods often required a different number of years of schooling. In order to achieve consistency of the measures of education across individuals in different years of the survey we use a categorical variable indicating the highest academic degree obtained. The most appropriate classification given the size and nature of our sample is a three-category measure of educational attainment, as follows: secondary school or below, technical school (full secondary education plus some professional training or attendance at a technical trade school, which includes technical, medical, music, pedagogical or art school) and finally tertiary (university or equivalent) education. More detailed breakdowns gave either too small samples or inconsistent results due to memory lapses in older individuals. 
The indicators for occupation are created according to the first digit of the ISCO-88 codes, but because some related occupational groups ended up with too small a number of respondents we aggregated further. We merged officials, managers and professionals; clerks and service workers; and skilled agricultural and fishery workers and unskilled workers, guided mainly by the fact that average wages within these three categories of workers were similar across the group.

A peculiarity of the Russian economy is the considerable heterogeneity of the distribution of human capital across geographic regions and settlements of a different size. Economic activity in Russia is concentrated in places where the state authorities are situated, as well as in regions associated with the extraction and processing of minerals and the transportation of the extracted products. In this regard, the Moscow region is of particular importance for the economy. The Russian centres of economic activity often coincide with centres of professional training. All of the above in combination with low internal labour mobility cause the large geographical variation of labour demand and supply. Indicators for region and the type of the settlement where a respondent is resident are used to proxy differences in the economic activity and resulting real wages in different local labour markets. There is a wealth of regional data and eight regions are distinguished: Central; North-Western; Volga; Southern; North-Caucasian; Ural; Siberian; and Far Eastern.

Table 1. Rules of the assignment of observations to settlement types

\begin{tabular}{|c|c|}
\hline Category & Population per locality \\
\hline Capital cities & 4.5 mln. or more \\
\hline Big cities & $0.8-1.5$ mln. \\
\hline Medium-sized cities & $180-800$ thousands \\
\hline Small towns & $30-130$ thousands \\
\hline The countryside & less than 30 thousands \\
\hline
\end{tabular}

Assigning observations to settlement types is generally guided by population size as shown in Table 1 . In addition to these rules some special rules 
are applied to assign settlements located in the Moscow administrative region. Due to the fact that these localities are close to the city of Moscow, the demand for labour from outside the locality is generally high, so that average earnings in localities in the Moscow region are almost as high as they are in Moscow. But residents of the city of Moscow and of the settlements located in the Moscow region are very different in terms of educational attainments. Average educational attainment in the Moscow region is considerably lower than it is in the city and comparable to that of persons living in other noncapital settlements of a corresponding size. We interpret these differences as resulting from mobility of labour between Moscow and its region but immobility of school children who attend school according to habits and customs in their local area. Consequently, we reclassified settlements located in the Moscow region as capital cities in equations (1)-(3), to avoid biasing the results of the smaller categories.

A person is defined as married if he or she cohabits with another, irrespective of whether the marriage is officially registered or not. Apart from preferring this definition because official registration is sometimes connected with religion or other factors that are not relevant to our study, this definition of marriage is also necessitated by the survey questionnaire, which did not distinguish in all years whether a marriage is registered or not.

Given our interest in estimating the impact of informal networks on the transmission of earnings potential from parents to children, ethnic origin can be an important influence, with non-Russians placed at a disadvantage. The RLMS data set reports several ethnic groups or nationalities living in Russia and we aggregate them into four groups. The first is the core group of Russians, Ukrainians and Belorussians. The second group encompasses Christian/European groups not included in the first group, whose origins are mainly Polish, Spanish, Armenian and some others. The third group includes mainly Islamic people such as the Tartars and the Muslims of Central Asia and North Caucasus. Other nationalities such as the Buryats, the Chuvash and the Kalmyks are aggregated into the fourth group.

Six periods encompassing children born in 1947-55, 1956-60, 1961-65, 1966-70, 1971-75 and 1976-80 are identified and cohort (time) dummies are 
included in all regressions. Children born in 1981-83 are the default group. Because older workers of both genders are under-represented in the samples and equation (5) is estimated with a smaller sample size, for this equation we aggregate the cohorts into three, one for the older ones born in 1947-75, one for the younger cohorts born in 1976-1980 and the reference group born in 1981-83.

Various measures of household characteristics are included in our regressions. The definition of a household in the RLMS includes people living together and having common income and expenditures, including unmarried children under 18 who study in a different population centre. The total number of family members, the number of children 17 or under and the number of children 3 or under are used as measures of household composition. The variable for residence ownership takes 1 for individuals living in their own dwelling and 0 for those occupying a rented property or living in a dormitory. Car ownership takes value 1 for all members of the household if there is at least one passenger car at the disposal of the household, and 0 otherwise. The living-space square of dwelling specifies the number of square meters of living-space at the disposal of the household.

Several time series published by the state statistical agency Rosstat are used in our estimation. Nominal income measures by region are adjusted by the cost of a consumer basket by region to arrive at real regional incomes. Any variable entering equations (1)-(5) is defined as the average for an individual taken over all non-missing values in all rounds of the survey in which an individual participated. The averages of binary dummy variables are then rounded to the nearest integer to keep the binary format. The averages are estimated on the sample of individuals of age 30-65 to exclude those who are at the beginning of their career, whose income is subject to measurement error.

Because of data availability, we used slightly different samples across the estimated equations, aiming always to get the maximum information in each. Appendix Table 5 shows all the descriptive statistics of our samples. Equations (1) and (2) were estimated with the sample shown in column 1 of Table 5. It includes all parent-child pairs, of either gender, who reported earnings 
at the primary place of work in at least five rounds of the survey (and have at least one observation on the other variables included in the regressions). If both parents report earnings and education the parent with the higher income is used.

Equation (3) consists of the same variables as equation (2) except for the omission of parents' earnings and the inclusion of occupational dummies. The equation may contain parents who do not have income data and were therefore not present in the estimation of equation (2). In this case the education of the father is used or, if not available, that of the mother. Equation (4) is estimated on two different samples. The first sample is in column 3 of Table 5 and is for sons and fathers. The second, in column 4, estimates equations for daughters and fathers. Equation (5) repeats the estimation of equation (4) but also includes the father's earnings.

The variations in the mean values reported in Table 5 are not large but some comments are in order about the earnings variables and their implications for other variables. The mean year of birth is especially sensitive to the presence of earnings in the specification, given our way of averaging earnings over five years. When earnings are in the equation the sample includes only individuals who have reported earnings in at least five rounds of the survey. As the probability that young people report earnings increases with age, whereas for older people it decreases with age, the inclusion of earnings of children raises the mean age, whereas the inclusion of parents' earnings lowers the mean age. This explains the differences in mean age across the columns in Table 5 .

Finally we need to point out a caveat about the RLMS survey, which does not chase individuals who change locality. If family networks and labour market influences are stronger in the family's local area, persons who move out should expect a diminished impact of parents' networks on their own income. As internal migration in Russia is low, however, this should not introduce a serious bias in our estimates but it should be noted that our estimates are for parents and children who live in the same locality. 


\section{Econometric specification and estimation results}

In order to estimate our model we first need to assign a good measure of permanent earnings to parents and children. As we already noted, permanent earnings are obtained as the residuals of a regression of current real monthly earnings on a vector of characteristics that remove temporary influences. The objective is to obtain an underlying rate of return to human capital for each person.

Age and hours worked are two obvious variables whose influence on the rate of return to human capital should be netted out. A more difficult issue arises because of the transition of Russia from a planned economy to a market economy in the 1990s. Human capital acquired before the transition was directed to different activities from the ones available in the market economy of later years, and so was less productive than human capital acquired after the transition. In order to correct for this change we introduce the birth year in the earnings regression, and refer to it as a cohort effect. Any other cohort effects may also be picked up by this procedure.

General macroeconomic effects are normally netted out by introducing year dummies, but having introduced age and cohort effects we would not be able to identify the year effects. One possibility is to use average earnings in the RLMS in place of year dummies to pick up macro effects, but because the RLMS is not a balanced survey over incomes this may not be a good proxy. The RLMS was not designed to represent the working population and although the moments of the distribution of earnings reported in the RLMS are close to the ones available in the Rosstat national series, some differences exist. In particular, the sample mean of earnings varies from period to period due to attrition, the addition of new households, movements in and out of unemployment, changing occupations and industries by some workers, and so on. For this reason we introduce extraneous information obtained from Rosstat, in the form of the real wage index, which is balanced over the whole economy (see also Borisov, 2007). The real wage index is the ratio of average real wages in period $t$ to average real wages in some initial period $0: R W I_{t}=A R W_{t} / A R W_{0}$. The earnings function with the logarithm of the 
real wages index estimated on the repeated cross-sections is:

$$
\ln R W_{i t}=k_{0}+k_{1} \ln R W I_{t}+\mathbf{K V}_{i t}+e_{i t 6}
$$

where $\ln R W_{i t}$ is the logarithm of the individual's real monthly earnings and $\mathbf{V}_{i t}$ is the vector of the other variables that we discussed. Since $\ln R W I_{t}=$ $\ln A R W_{t}-\ln A R W_{0}$ and $\ln A R W_{0}$ is independent of time and person, equation (6) gives

$$
\ln R W_{i t}=\left(k_{0}-k_{1} \ln A R W_{0}\right)+k_{1} \ln A R W_{t}+\mathbf{K V}_{i t}+e_{i t 6}
$$

To the extent that the logarithm of average real wages in period $t, \ln A R W_{t}$, corresponds to the true underlying period mean of the dependent variable it picks up the average effect of macroeconomic factors on real earnings in period $t$; it proxies for period, being unrelated with age and cohort. The results reported by Borisov (2007) confirm that $\ln R W I_{t}$ is a good proxy for period.

Equation (6) is our preferred equation from which we obtain permanent earnings, after we correct for possible selection bias. Selection bias may arise for two reasons. First, if people's decisions about working or not working depend on earnings, people with low earning capacity will be under-represented in the sample. Second, reporting earnings may be dependent on the level of earnings. Aivazjan and Kolenikov (2001) show that the probability of responding is a negative function of household's expenditures and so households with higher earnings are less likely to report. Selection bias because of the participation decision is likely to be relevant only for women, but we cannot estimate equation (6) on the female sample, because Rosstat reports the real wages index for all working individuals, not males and females separately. Correction for the entire sample together is also not possible because of the absence of hours information for non-participants. Had the elasticity of earnings with respect to hours been 1 , or close to it, we could have avoided this problem by dividing earnings by the number of hours of work to arrive at hourly wages but results reported in Appendix Table 6 indicate that the 
elasticity of earnings with respect to hours worked is in the range 0.3-0.4.

Any selection bias from failure to report, however, can easily be accounted for. The earnings equation becomes:

$$
\begin{aligned}
\ln R W_{i t} & =g_{0}+\sum_{n} g_{1 n} D B Y_{n i}+\sum_{m} g_{2 m} D A_{m i t}+g_{3} \ln R W I_{t} \\
& +g_{4} \ln H R S_{i t}+e_{i t 7}
\end{aligned}
$$

with the selection equation,

$$
\begin{aligned}
\text { Sel }_{i t} & =h_{0}+h_{1} M A R S T_{i t}+h_{2} O W N H S_{i t}+h_{3} S Q L I V E_{i t}+h_{4} O W N C A R_{i t} \\
& +h_{5} N C H L D 3_{i t}+h_{6} A G E_{i t}+h_{7} A G E S Q_{i t}+e_{i t 8} .
\end{aligned}
$$

In this equation the indices $i, n, m$ and $t$ stand for individual, birth year, age and period respectively; $\ln R W_{i t}$ is the logarithm of real monthly earnings from the primary place of work; $D B Y_{n i}$ are dummy variables for birth year defined as $D B Y_{n i}=1$ if the birth year is the year of observation minus the respondent's age plus one and $D B Y_{n i}=0$ otherwise; $D A_{m i t}$ are dummies for age with the one-year window: $D A_{m i t}=1$ if the age of the respondent is the year of observation less the year of birth plus one and $D A_{m i t}=0$ otherwise; $\ln R W I_{t}$ is the logarithm of the real wages index; $\ln H R S_{i t}$ is the logarithm of working hours; $S e l_{i t}$ is a dummy for selection, which takes value 1 for working individuals who reported earnings and 0 for working individuals who refused to declare earnings from the primary place of work; $M A R S T_{i t}$ is a dummy for marital status; $O W N H S_{i t}$ is a dummy for residence; $S Q L I V E_{i t}$ are the square meters of a living space; $O W N C A R_{i t}$ is a dummy for car ownership; $N C H L D 3_{i t}$ is the number of children aged three or less; $A G E_{i t}$ is years of age and $A G E S Q_{i t}$ the same squared.

Equations (8) and (9) are estimated on the repeated cross-sections, including observations for all the respondents from all the rounds of the RLMS survey. The residuals from equation (8) are the measure of the permanent incomes that we use in equations (1)-(3), and (5). As an individual is normally represented by several observations in equations (8)-(9) and all children are 
selected in equations (1)-(5), some individuals and parents appear more than once in the estimated equations. We use the robust estimator that adjusts the standard errors to allow for the intragroup correlation within the clusters of individuals or parents. Equations (1) and (2) are estimated by OLS and quantile regressions. Equation (3) is estimated by OLS only.

As stated in Section 3, the parents in equations (1)-(3) are selected on the basis of gender and certain income characteristics. To ensure the consistency of estimates, equations (1) and (2) were augmented by two dummies, the first of which is parent's gender, and the second taking the value 1 if the parent is chosen because he or she earns more than the other parent.

The dummy variable of occupation entering equation (3) is constructed as an individual mean averaged over periods. The averaging of a time-varying characteristic increases the error-in-measurement, which causes the downward bias of the estimate. Therefore, one may expect the estimates of the effect of occupation from equation (3) to be lower bounds of the true effects.

In equations (4) and (5) the dependent variable is a categorical one indicating the level of children's education as one of three levels, so the ordered response model is used to estimate the effect of parent's educational attainments on their children's education. As the distribution of residuals from equations (4) and (5) appear to be closer to a normal distribution than to a logistic one, the ordered probit model is used.

The earnings-age profile is estimated by the Heckman selection procedure according to equations (8) and (9). The sample includes the data from all the waves of the survey on males and females aged 25 to 65 years who reported earnings and hours at the primary place of work. Selected estimates are presented in Appendix Table 6. The correlation coefficient between the wage and selection equations is statistically significant. The estimates of the selection equation have predictable signs. The selection equation confirms that individuals with more assets are less likely to declare earnings.

The earnings-age profile is convex upward having the expected shape, with a peak at age 45.5. The cohort effect is maximum for those born in 1983. The 1983 cohort entered the labour market mainly in the first half of the 2000s, when the demand for labour grew rapidly after the financial crisis 
of the late 1990s. As we would expect given the structural transformation of the early 1990s, the cohort effect decreases gradually as we move from 1983 back; the results indicate that the human capital of older people is valued less than that of younger ones.

The estimate of the logarithm of the real wage index is 0.87 and strongly significantly different from both 0 and 1 . The high value of the estimate confirms that the index is a good measure of the average real wages of our sample, but the fact that it is less than 1 shows that the wages of respondents in our sample are less cyclical than the average. The estimate of the logarithm of monthly hours is low, at 0.35 , confirming our claim that dividing monthly earnings by hours worked is not a good way of obtaining hourly wages as the rate of return to human capital (see also Maltzeva, 2009, for a similar conclusion).

The residuals from equation (8) are used as the measure of the permanent income of children and parents in equations (1)-(3) and (5).

Table 7 presents the OLS estimates of equation (1). The earnings elasticity is about 0.33 and strongly significant. Equation (1) is also estimated for the 20th, 40th, 60th, and 80th quantiles of the distribution of its dependent variable by means of the quantile regression. The estimates of the effect of parent's earnings for the specified quantiles are shown in Table 2.

Table 2. The estimates of the earnings elasticity for quantiles

\begin{tabular}{|c|c|c|c|c|}
\hline & \multicolumn{4}{|c|}{ Quantiles } \\
\hline & 0.20 & 0.40 & 0.60 & 0.80 \\
\hline The earnings & $0.2933^{* * *}$ & $0.3537^{* * *}$ & $0.3744^{* * *}$ & $0.4695^{* * *}$ \\
elasticity & {$[0.0947]$} & {$[0.0738]$} & {$[0.0709]$} & {$[0.0893]$} \\
\hline
\end{tabular}

*** Significant at .01 level.

Bootstrap standard errors are in brackets.

The results of the quantile regressions demonstrate heterogeneities in the estimates, with the earnings elasticity increasing as we move up the (children's) wage distribution. But the Wald test of the hypothesis that the earnings elasticities estimated for the 20th and 80th quantiles are equal to 
each other cannot reject equality at the $10 \%$ level. So although the change in the point estimate is evident and monotonic, it is not statistically significant.

The OLS estimates of equation (2) are in Appendix Table 8. The elasticity with respect to parent's permanent earnings is 0.25 and since education variables are also in the regression, it picks up the intergenerational earnings elasticity that is due to the family's social networks. If we take the 0.33 estimate from equation (1) as the total effect, we conclude that most of the transfer, about three-quarters, is due to networks and the remainder quarter to educational transfers.

As expected, own education is a significant determinant of earnings. Technical school graduates receive a $14 \%$ wage premium, whereas university graduates gain an extra 35\% increase in their permanent income when compared with the default group of no education beyond secondary level. The effect of parent's education on children's earnings is not significantly different from 0 . It is possible that the endogeneity of the independent variables in equation (2) masks the full effect of parent's education. Parent's education influences their children's educational attainment and also determines parent's earnings. But the fact that once these indirect effects are controlled for there is no significant effect of parent's education remaining, indicates that highly-paid parents, but not necessarily highly-educated ones, provide their children with beneficial social connections. This is also valid if households with highly-educated parents cultivate a stronger work ethic: such an ethic is not necessarily accompanied by a higher monetary return.

Equation (2) is also estimated for the 20th, 40th, 60th, and 80th quantiles of the distribution of children's earnings by means of the quantile regression. The selected estimates for the specified quantiles are shown in Appendix Table 9. The estimates do not reveal any consistent pattern across quantiles (note that the sample for some of these quantiles is very small).

The estimates of equation (3) are in Appendix Table 10. Comparing the estimates of equations (2) and (3) reveals that the inclusion of occupational dummies does not change the effect of the educational attainment of children. Other results show that the effects of ethnic background are close to 0 and statistically insignificant for all ethnic groups. The type of the residential 
settlement, however, affects long-term earnings. The difference in earnings between those who live in the metropolitan area and in the countryside is statistically significant at the $1 \%$ level. As expected, wages are positively correlated with the size of settlement. People living in rural areas on average earn $46 \%$ less than those with similar qualifications in the metropolitan areas. Region plays a less important role, with only the North Western Federal region associated with higher wage earnings, most likely because of compensation for poor climatic conditions. The occupational differences are also as expected, with clerks and service workers, skilled agricultural and fishery workers and the unskilled earn significantly less than officials, managers, and professionals, even when educational attainment is taken into account. The gender difference in earnings is large and strongly significant, at a $41 \%$ premium of male over female workers.

Equation (4) estimates the transmission of educational attainment from parents to children. The results of the ordered probit for the sample of sons and fathers are presented in Appendix Table 11 and those for daughters and fathers in Appendix Table 12. Examination of the results shows that father's education attainment strongly affects educational achievements of both sons and daughters, with very similar point estimates. Other estimates show that Muslim children, regardless of gender, are less likely to graduate from a technical school or university than the reference group consisting of Russian, Ukrainian, and Belorussian. Compared to the Central Federal region which is the reference one, the expected level of education of both sons and daughters is significantly lower in the Urals and Siberian Federal regions. The latter are regions that specialize in the extraction and processing of raw materials, which require less highly-educated labour.

Educational attainment also depends on year of birth. The probability of sons and daughters born in 1981-83 to achieve a higher level of education is significantly larger than that of other children. Children from the 198183 cohort made the decision about education in the late 1990s and early 2000s, when the demand for highly-educated workers was increasing fast. The difference in the acquisition of higher education is particularly high when we compare children born in 1981-83 with those born in 1971-1975. The 
latter cohort completed secondary school in late 1980s and early 1990's, when the transition to the market economy started and there was a deep drop in the demand for skilled labour. The impact of such differences on earnings and productivity is long-lasting and shows how temporary falls in economic activity can have long-term effects on the economy.

The composition of the family has an impact on the educational attainment of daughters, in that daughters in larger households do not acquire as much higher education as daughters in other households. In larger households daughters are more likely to drop out of formal education after secondary school and, one assumes, devote more time to household work such as childcare or elderly care.

Equation (5) adds parent's permanent earnings to the explanatory variables of equation (4). The estimation results are shown in Appendix Table 13. The results show that once the educational attainment of the father is controlled for, father's income does not play a role in the educational investments in the children (male or female). This shows both a strong intergenerational linkage in educational attainments but also the absence of financial constraints for children in higher education, which would have made parent's income a more important factor in their education decision. We note that in the USSR education was completely free and even after the transition a significant number of college and university students had been attending on a non-tuition basis. According to the Russian Statistical Yearbook 2014, only one third of all the university students paid for education in 2000, though this share increased to $50 \%$ by 2005 and it remained about $55-60 \%$ in subsequent years. As the samples estimated in this paper cover respondents born before 1984, most children had graduated when education was offered on a non-tuition basis. The result may not hold for later cohorts who attended after tuition became more widespread. The results estimated in this context are also consistent with our earlier finding, in equations (1) and (2), that the main channel of transmission of earnings capacity from parents to children is a direct one that utilizes other channels and not one that works through the educational investments of parents in their children. 


\section{Intergenerational educational mobility}

The results of the estimation of the ordered probit model can be used to predict the probabilities of achieving each level of educational qualification and compute the intergenerational mobility probabilities across educational groups. Equation (4) is used for that purpose, because its bigger sample gives more accurate and consistent estimates than equation (5). Table 3 displays the predicted probabilities of achieving the levels of education for a child of the Russian, Ukrainian or Belorussian nationality, born in 1971-1975, who is resident in the Volga region in the countryside and whose household's composition corresponds to the means of the respective samples.

Table 3. The predicted conditional probabilities of achieving education attainments, the rural areas of the Volga region, cohort born in 1971-1975.

\begin{tabular}{|c|c|c|c|c|c|c|}
\hline & \multicolumn{3}{|c|}{ Son's level of education } & \multicolumn{3}{c|}{ Daughter's level of education } \\
\hline $\begin{array}{c}\text { Father's level of } \\
\text { education }\end{array}$ & I & II & III & I & II & III \\
\hline I & 0.745 & 0.223 & 0.032 & 0.511 & 0.388 & 0.101 \\
\hline II & 0.551 & 0.355 & 0.094 & 0.323 & 0.461 & 0.216 \\
\hline III & 0.385 & 0.430 & 0.185 & 0.174 & 0.447 & 0.379 \\
\hline
\end{tabular}

I - secondary or below secondary education; II - technical school; III university or higher.

Table 3 demonstrates high intergenerational persistence in educational qualifications for lower grades, as shown by the values of the diagonal terms. However, it also shows mobility, especially for men. Generally, upward mobility is more prevalent for daughters, as shown by the higher entries in the cells to the right of the diagonal, than it is for sons, who are characterized by more downward mobility.

Consider first mobility across adjacent categories. Perhaps surprisingly, Table 3 shows that sons with fathers who have beyond secondary education are likely to be less well educated than their fathers, and the same holds for daughters but only if the father has a university degree. Next consider longdistance mobility, defined as the probability of a person from the bottom or 
top tail of the distribution to end up in the opposite tail. Bottom-to-top education mobility is measured as the probability of the child achieving tertiary education conditional on the father having secondary or below-secondary education. Conversely, top-to-bottom education mobility is measured as the probability of the child belonging to the low-educated category conditional on the father having tertiary education.

It follows from Table 3 that the bottom-to-top probabilities for sons is 0.032 and for daughters 0.101 , whereas the top-to-bottom probabilities are 0.385 and 0.174 respectively. The downward mobility for males may seem surprising but one can argue that it is peculiar to the 1971-1975 cohort, which made their educational decisions at the time of the transition. The drop in demand for skilled labour was large at the time, especially outside the metropolitan areas. The probabilities improve somewhat when the Moscow and St. Petersburg metropolitan areas are considered instead of the Volga one, with the bottom-to-top mobility for sons increasing to 0.110 and the top-to-bottom decreasing to 0.180 . For daughters the bottom-to-top mobility increases to 0.329 and the top-to-bottom one falls to 0.038 .

In order to test further the hypothesis that educational mobility depends on the demand conditions for skilled labour, we also computed the transition probabilities for children of the 1981-1983 cohort, who entered education in the boom years around the new millennium. Official figures provided by the State Committee of the Russian Federation on Statistics (2002) and Rosstat (2014) show that total employment increased by 6.73 million persons in 20012013, whereas employment of officials, managers, and professionals increased by 6.65 million, so almost the entire increase in total employment between 2001 and 2013 can be accounted for by the increase in the employment of high-skilled labour. The estimates of equation (4) give the transition probabilities in Table 4, which is directly comparable to Table 3. 
Table 4. The predicted conditional probabilities of achieving education attainments, the rural areas of the Volga region, cohort born in 1981-1983.

\begin{tabular}{|c|c|c|c|c|c|c|}
\hline & \multicolumn{3}{|c|}{ Son's level of education } & \multicolumn{3}{|c|}{ Daughter's level of education } \\
\hline $\begin{array}{c}\text { Father's level of } \\
\text { education }\end{array}$ & I & II & III & I & II & III \\
\hline I & 0.575 & 0.341 & 0.084 & 0.375 & 0.448 & 0.177 \\
\hline II & 0.367 & 0.435 & 0.198 & 0.210 & 0.460 & 0.330 \\
\hline III & 0.223 & 0.443 & 0.334 & 0.099 & 0.385 & 0.516 \\
\hline
\end{tabular}

I - secondary or below secondary education; II - technical school; III university or higher.

Table 4 shows that as before, upward mobility is more likely for females than males, who still exhibit at least as much downward mobility as upward. However, transitions generally improve. The bottom-to-top transition probabilities for the 1981-83 cohort of sons and daughters increases by up to 0.084 and 0.177 respectively, or by 2.6 and 1.75 times, as compared with the corresponding figures for the 1971-75 cohort. The top-to-bottom transitions for the 1981-83 cohort of sons and daughters are 0.223 and 0.099, both more than $40 \%$ lower than the equivalent ones of the 1971-75 cohort. The intergenerational transmission of educational attainment is even more pronounced for children living in the metropolitan areas, with the bottom-to-top transition for sons increasing to 0.224 and the top-to-bottom decreasing to 0.083. For daughters the bottom-to-top transition increases to 0.462 and the top-to-bottom one falls to 0.017 .

\section{Conclusions and policy implications}

In this paper we estimated the intergenerational transition of earnings in post-transition Russia, which takes place either through educational qualifications that correlate across generations or through other channels, such as family and professional networks. Our estimation results, with a longitudinal data set that extends from 1994 to 2013, show that the intergenerational transmission of earnings is high and, importantly, the channels through which 
it is manifested are the informal networks not picked up by formal education. In other words, high-income parents do not necessarily invest more in their children's education, but despite this, their children are more likely to end up being higher earning individuals than the children of poorer families. The intergenerational earnings elasticity is estimated to be equal to 0.33 on average, and although it rises as incomes rise, the estimated difference for the $20 \%$ and $80 \%$ quantiles of the earnings distribution is not statistically significant. Other countries with similar magnitudes of the international earnings elasticity include Italy, the United States and France. In these countries, however, the high values of the intergenerational earnings elasticity is broadly attributed to private investments in children's human capital resulting from lower public expenditures on education (Black and Devereux, 2011). The Russian case seems different, because a relatively large value of the elasticity is combined with tuition-free education prevailing among the respondents in our sample.

The high intergenerational earnings elasticity implies low earnings mobility, so the mechanisms behind it can be considered to be obstacles to the improvement in the welfare of people at the bottom of the earnings distribution. The fact that the causes of the high elasticity are not related to access to education makes it more difficult for policy to break this barrier because it is not obvious where it should be targeted. For example, the strong intergenerational income transition could be due to closed professions whereby sons and daughters enter the father's or mother's profession more easily than those from outside could do; it could be due to social networks, where parents influence their colleagues and acquaintances when their children apply for jobs; or it could be the outcome of corruption where corrupt practices are passed down from parents to children. It is clearly the case, however, that a policy aimed at the enhancement of transparency and competition in the labour market could shed more light on the correlations identified in this paper and promote more intergenerational earnings mobility.

As in other studies we find that own education contributes to one's permanent earnings, so improving one's own education is an effective way of improving one's position in the income distribution, especially for children 
from low-income families. The fact that we find that parents' income does not influence educational attainment is indirect evidence that there are no binding budget constraints in educational choices. This plausible finding may be due to the fact that most of the children of our sample graduated during a period when education in Russia was offered free of tuition. This could change as tuition is gradually being introduced in many institutes of higher education.

The results show that in contrast to parents' income, parents' education is a strong influence on children's educational attainment. So enhancing one's education has beneficial intergenerational effects on children's education too. The mechanism is not through budget constraints, but through incentives and knowledge of educational opportunities and their contribution to career enhancement.

An important finding of our study is that controlling for parent's education and income, the local labour market and the state of the macro economy are strong influences on the acquisition of education by children. In times of lower demand for skilled labour, fewer children enter institutes of higher education. Of course, this is inefficient given the length of macro recessions and the impact of education on lifecycle earnings and introduces cohort effects on earnings well into adult life. Children who live in larger local markets are more likely to pursue higher education, because of the many more opportunities offered for skilled labour in bigger cities. In addition to this effect, cohort effects are estimated. Children belonging to our youngest cohort, born in 1981-1983, were more likely to graduate from a university than earlier cohorts were. When the children born in 1981-83 were making their educational choices the demand for skilled labour in Russia was the highest in the post-transition era. Our findings point to the importance of promoting the creation of jobs for skilled labour in depressed areas or in rural environments in order to give incentives for children from those areas to pursue more education. 


\section{References}

[1] Aivazjan, S. and S. Kolenikov (2001). "Poverty and Expenditure Differentiation of the Russian Population". EERC's Working Paper Series, $01 / 01$.

[2] Becker, G. and N. Tomes (1979). "An Equilibrium Theory of the Distribution of Income and Intergenerational Mobility". Journal of Political Economy, 87, 1153-1189.

[3] Berger, M. C., J. S. Earle and K. Z. Sabirianova (2001). "Worker training in a restructuring economy: Evidence from the Russian transition", in Solomon Polachek (ed.) Worker Wellbeing in a Changing Labor Market (Research in Labor Economics, Volume 20) Emerald Group Publishing Limited, 159-190.

[4] Black, S. E. and P. J. Devereux (2011). "Recent Developments in Intergenerational Mobility". In: Handbook of Labor Economics, Vol. 4B. Edited by D. Card and O. Ashenfelter. Elsevier B.V., North Holland.

[5] Borisov, G. (2007). "The Vintage Effect on the Russian Labor Market". Eastern European Economics, 45, 23-51.

[6] Bratberg, E., O. A. Nilsen and K. Vaage (2005). "Intergenerational Mobility: Trends Across the Earnings Distribution". University of Bergen Department of Economics Working Papers in Economics, No. 04/05.

[7] Causa, O., S. Dantan and Å. Johansson (2009). "Intergenerational Social Mobility in European OECD Countries". OECD Economics Department Working Papers, No. 709.

[8] Chevalier, A., C. Harmon, V. O' Sullivan and I. Walker (2013). "The impact of parental income and education on the schooling of their children". IZA Journal of Labor Economics, 2:8.

[9] Clark, A. (2003). "Returns to Human Capital Investment in a Transition Economy: The Case of Russia, 1994-1998". International Journal of Manpower, 24, 11-30. 
[10] D'Addio, A. C. (2007). "Intergenerational Transmission of Disadvantage: Mobility or Immobility across Generations? A Review of the Evidence for OECD Countries". OECD Social, Employment and Migration Working Papers, No. 52.

[11] Dearden, L., S. Machin and H. Reed (1997). "Intergenerational Mobility in Britain". Economic Journal, 107, 47-66.

[12] Gimpelson, V. and R. Kapeliushnikov, eds. (2007). Wages in Russia: Their Evolution and Differentiation. Moscow: HSE Publishing House. (in Russian)

[13] Gorodnichenko, Y. and K. Sabirianova Peter (2005). "Returns to Schooling in Russia and Ukraine: A Semiparametric Approach to CrossCountry Comparative Analysis". Journal of Comparative Economics, 33, 324-350.

[14] Lukiyanova, A. (2010). "The return to education: what the metaanalysis shows?" Higher School of Economics Economic Journal, 14, 326-348. (in Russian)

[15] Lukiyanova, A. and A. Oshchepkov (2012). "Income mobility in Russia (2000-2005)". Economic Systems, 36, 46-64.

[16] Maltzeva, I. (2009). "Labor mobility. What is the return on specific human capital in Russia?" Higher School of Economics Economic Journal, 243-278. (in Russian)

[17] Solon, G. (1992). "Intergenerational Income Mobility in the United States". American Economic Review, 82, 393-408.

[18] Solon, G. (1999). "Intergenerational Mobility in the Labor Market". In: Handbook of Labor Economics, Vol. 3A. Edited by D. Card and O. Ashenfelter. Elsevier B.V., North Holland. 


\section{Appendix}

Table 5. Descriptive statistics on estimated samples. ${ }^{1}$

\begin{tabular}{|c|c|c|c|c|c|c|}
\hline Sample & 1 & 2 & 3 & 4 & 5 & 6 \\
\hline $\begin{array}{l}\text { Estimated } \\
\text { equation }\end{array}$ & $\begin{array}{l}(1) \\
\text { and } \\
(2)\end{array}$ & (3) & (4) & (4) & (5) & (5) \\
\hline Sample size & 250 & 733 & 848 & 803 & 240 & 239 \\
\hline $\begin{array}{l}\text { Parent's } \\
\text { permanent } \\
\text { earnings }^{2}\end{array}$ & $\begin{array}{c}0.018 \\
{[0.568]}\end{array}$ & & & & $\begin{array}{c}0.200 \\
{[0.549]}\end{array}$ & $\begin{array}{c}0.231 \\
{[0.549]}\end{array}$ \\
\hline Year of parents' & 1948.7 & 1943.0 & 1947.5 & 1947.7 & 1951.9 & 1951.7 \\
\hline birth & {$[5.261]$} & {$[7.563]$} & {$[8.237]$} & [8.179] & {$[5.571]$} & [5.158] \\
\hline Female parents & 0.596 & 0.591 & 0.000 & 0.000 & 0.000 & 0.000 \\
\hline $\begin{array}{c}\text { Parent's education } \\
\text { below-secondary or } \\
\text { secondary }\end{array}$ & 0.312 & 0.477 & 0.458 & 0.416 & 0.325 & 0.331 \\
\hline $\begin{array}{l}\text { Parents with } \\
\text { technical school }\end{array}$ & 0.480 & 0.359 & 0.384 & 0.412 & 0.496 & 0.477 \\
\hline $\begin{array}{l}\text { Tertiary parent's } \\
\text { education }\end{array}$ & 0.208 & 0.164 & 0.158 & 0.172 & 0.179 & 0.192 \\
\hline $\begin{array}{l}\text { Children's } \\
\text { permanent } \\
\text { earnings }^{2}\end{array}$ & $\begin{array}{c}0.020 \\
{[0.539]}\end{array}$ & $\begin{array}{l}-0.009 \\
{[0.553]}\end{array}$ & & & & \\
\hline Year of children's & 1973.5 & 1969.7 & 1974.4 & 1974.9 & 1977.3 & 1977.9 \\
\hline birth & {$[3.792]$} & {$[6.052]$} & [6.418] & [6.413] & {$[4.502]$} & {$[4.070]$} \\
\hline Female children & 0.548 & 0.574 & 0.000 & 1.000 & 0.000 & 1.000 \\
\hline $\begin{array}{c}\text { Capital cities' } \\
\text { residents }^{3}\end{array}$ & 0.168 & 0.194 & 0.118 & 0.119 & 0.117 & 0.092 \\
\hline Big cities' residents & 0.228 & 0.172 & 0.120 & 0.131 & 0.150 & 0.138 \\
\hline $\begin{array}{c}\text { Middle-sized cities' } \\
\text { residents }^{3}\end{array}$ & 0.224 & 0.199 & 0.217 & 0.242 & 0.233 & 0.243 \\
\hline
\end{tabular}




\begin{tabular}{|c|c|c|c|c|c|c|}
\hline Sample & 1 & 2 & 3 & 4 & 5 & 6 \\
\hline $\begin{array}{l}\text { Small cities' } \\
\text { residents }^{3}\end{array}$ & 0.200 & 0.207 & 0.188 & 0.207 & 0.233 & 0.209 \\
\hline $\begin{array}{l}\text { Countryside's } \\
\text { residents }^{3}\end{array}$ & 0.180 & 0.228 & 0.357 & 0.301 & 0.267 & 0.318 \\
\hline Married children & 0.664 & 0.643 & 0.587 & 0.593 & 0.613 & 0.628 \\
\hline $\begin{array}{l}\text { Children living } \\
\text { apart from parents }\end{array}$ & 0.276 & 0.150 & 0.166 & 0.188 & 0.304 & 0.326 \\
\hline $\begin{array}{l}\mathrm{N} \text { of members in } \\
\text { the children's } \\
\text { household }\end{array}$ & & & $\begin{array}{c}4.176 \\
{[1.769]}\end{array}$ & $\begin{array}{c}4.317 \\
{[1.614]}\end{array}$ & $\begin{array}{c}3.877 \\
{[1.404]}\end{array}$ & $\begin{array}{c}4.099 \\
{[1.574]}\end{array}$ \\
\hline $\begin{array}{c}\mathrm{N} \text { of children aged } \\
\text { under } 3 \text { in the } \\
\text { children's } \\
\text { household }\end{array}$ & & & $\begin{array}{c}0.181 \\
{[0.351]}\end{array}$ & $\begin{array}{c}0.199 \\
{[0.362]}\end{array}$ & $\begin{array}{c}0.204 \\
{[0.370]}\end{array}$ & $\begin{array}{c}0.251 \\
{[0.382]}\end{array}$ \\
\hline $\begin{array}{l}\text { N of children aged } \\
\text { under } 17 \text { in the } \\
\text { children's } \\
\text { household }\end{array}$ & & & $\begin{array}{c}0.608 \\
{[0.775]}\end{array}$ & $\begin{array}{c}0.998 \\
{[0.779]}\end{array}$ & $\begin{array}{c}0.618 \\
{[0.708]}\end{array}$ & $\begin{array}{c}1.070 \\
{[0.745]}\end{array}$ \\
\hline $\begin{array}{c}\text { Children's } \\
\text { education } \\
\text { below-secondary or } \\
\text { secondary } \\
\end{array}$ & 0.224 & 0.250 & 0.377 & 0.214 & 0.271 & 0.138 \\
\hline $\begin{array}{l}\text { Children with } \\
\text { technical school }\end{array}$ & 0.404 & 0.442 & 0.390 & 0.396 & 0.400 & 0.335 \\
\hline $\begin{array}{l}\text { Tertiary children's } \\
\text { education }\end{array}$ & 0.372 & 0.308 & 0.232 & 0.390 & 0.329 & 0.527 \\
\hline $\begin{array}{l}\text { Russian, } \\
\text { Ukrainian, or } \\
\text { Belorussian } \\
\text { children }\end{array}$ & 0.924 & 0.899 & 0.800 & 0.880 & 0.888 & 0.908 \\
\hline
\end{tabular}




\begin{tabular}{|c|c|c|c|c|c|c|}
\hline Sample & 1 & 2 & 3 & 4 & 5 & 6 \\
\hline $\begin{array}{c}\text { Christian } \\
\text { (non-Russian) } \\
\text { children }\end{array}$ & 0.028 & 0.022 & 0.040 & 0.020 & 0.033 & 0.025 \\
\hline Moslem children & 0.032 & 0.059 & 0.130 & 0.075 & 0.037 & 0.050 \\
\hline $\begin{array}{c}\text { Children of other } \\
\text { nationalities }\end{array}$ & 0.016 & 0.020 & 0.030 & 0.025 & 0.042 & 0.017 \\
\hline $\begin{array}{l}\text { The Central } \\
\text { region's residents }\end{array}$ & 0.308 & 0.322 & 0.252 & 0.270 & 0.288 & 0.331 \\
\hline $\begin{array}{l}\text { The North Western } \\
\text { region's residents }\end{array}$ & 0.072 & 0.083 & 0.086 & 0.086 & 0.075 & 0.075 \\
\hline $\begin{array}{l}\text { The Volga region's } \\
\text { residents }\end{array}$ & 0.292 & 0.247 & 0.205 & 0.220 & 0.233 & 0.239 \\
\hline $\begin{array}{l}\text { The Southern } \\
\text { region's residents }\end{array}$ & 0.116 & 0.125 & 0.123 & 0.137 & 0.125 & 0.109 \\
\hline $\begin{array}{c}\text { The North } \\
\text { Caucasian region's } \\
\text { residents }\end{array}$ & 0.028 & 0.048 & 0.112 & 0.059 & 0.029 & 0.029 \\
\hline $\begin{array}{c}\text { The Ural region's } \\
\text { residents }\end{array}$ & 0.072 & 0.059 & 0.055 & 0.072 & 0.075 & 0.063 \\
\hline $\begin{array}{l}\text { The Siberian } \\
\text { region's residents }\end{array}$ & 0.100 & 0.098 & 0.109 & 0.099 & 0.117 & 0.100 \\
\hline $\begin{array}{l}\text { The Far Eastern } \\
\text { region's residents }\end{array}$ & 0.012 & 0.018 & 0.058 & 0.057 & 0.058 & 0.054 \\
\hline $\begin{array}{c}\text { Children employed } \\
\text { as army }\end{array}$ & & 0.003 & 0.008 & 0.001 & & \\
\hline $\begin{array}{c}\text { Children employed } \\
\text { as officials, } \\
\text { managers, and } \\
\text { professionals }\end{array}$ & & 0.244 & 0.190 & 0.287 & & \\
\hline $\begin{array}{l}\text { Children employed } \\
\text { as technicians }\end{array}$ & & 0.205 & 0.106 & 0.286 & & \\
\hline
\end{tabular}




\begin{tabular}{|c|c|c|c|c|c|c|}
\hline $\begin{array}{c}\text { Sample } \\
\begin{array}{c}\text { Children employed } \\
\text { as clerks and } \\
\text { service workers }\end{array}\end{array}$ & 1 & 2 & 3 & 4 & 5 & 6 \\
\hline $\begin{array}{c}\text { Children employed } \\
\text { as craft and related } \\
\text { trades }\end{array}$ & & 0.179 & 0.077 & 0.263 & & \\
\hline $\begin{array}{c}\text { Children employed } \\
\text { as machine } \\
\text { operators and } \\
\text { assemblers }\end{array}$ & & 0.143 & 0.258 & 0.035 & & \\
\hline $\begin{array}{c}\text { Children employed } \\
\text { as skilled } \\
\text { agricultural, } \\
\text { fishery and } \\
\text { unskilled workers }\end{array}$ & & 0.101 & 0.135 & 0.091 & & \\
\hline $\begin{array}{c}\text { Number of } \\
\text { observations with } \\
\text { non-missing } \\
\text { children's } \\
\text { occupation }\end{array}$ & & 733 & 726 & 696 & & \\
\hline
\end{tabular}

${ }^{1}$ Sample means with standard deviations in brackets and shares of specified groups.

${ }^{2}$ The sample mean of residuals of the target group from equation (8) averaged over 5 years or more.

${ }^{3}$ The settlements situated in the Moscow's administrative region (oblast') are classified as capital cities while estimating equations (1)-(3). They are classified according to their actual population while estimating equation (4) and equation (5). 
Table 6. The selected estimates of the wage equation by the Heckman selection estimator.

\begin{tabular}{|c|c|}
\hline $\begin{array}{c}\text { Log of the real wage } \\
\text { index }\end{array}$ & $0.8711^{* * *}[0.0243]$ \\
\hline $\begin{array}{c}\text { Log of hours monthly } \\
\text { worked at the } \\
\text { primary place }\end{array}$ & $0.3519^{* * *}[0.0111]$ \\
\hline Constant & $6.2933^{* * *}[0.0716]$ \\
\hline rho & $0.2887[0.0140]$ \\
\hline $\begin{array}{c}\text { Wald test of } \\
\text { independent } \\
\text { equations (rho }=0)\end{array}$ & $\operatorname{chi} 2(1)=378.95^{* * *}$ \\
\hline $\begin{array}{c}\text { Number of } \\
\text { observations }\end{array}$ & 77016 \\
\hline Censored observations & 2540 \\
\hline $\begin{array}{c}\text { Uncensored } \\
\text { observations }\end{array}$ & 74476 \\
\hline
\end{tabular}

The dependent variable of the wage equation is log of deflated monthly monetary earnings received at primary place of work. The observation is selected if earnings are reported, and not selected if the employed individual explicitly refuses to declare earnings.

*** Significant at .01 level.

Robust standard errors adjusted for 20628 clusters in individuals are in brackets. 
Table 7. The OLS estimates of equation (1).

\begin{tabular}{|c|c|c|c|}
\hline Parent's earnings $^{1}$ & $\begin{array}{c}0.3310^{* * *} \\
{[0.0583]}\end{array}$ & $\begin{array}{c}\text { The Southern } \\
\text { region }\end{array}$ & $\begin{array}{c}0.0367 \\
{[0.1174]}\end{array}$ \\
\hline $\begin{array}{c}\text { More-paid (1) or } \\
\text { solely available (0) } \\
\text { parent is selected }\end{array}$ & $\begin{array}{c}0.0442 \\
{[0.0680]}\end{array}$ & $\begin{array}{c}\text { The North } \\
\text { Caucasian region }\end{array}$ & $\begin{array}{c}-0.0832 \\
{[0.2301]}\end{array}$ \\
\hline Parent's gender & -0.0207 & The Ural region & -0.0306 \\
& {$[0.0663]$} & & {$[0.1327]$} \\
\hline Big cities ${ }^{2}$ & 0.1431 & The Siberian & -0.1779 \\
& {$[0.1351]$} & region & {$[0.1175]$} \\
\hline Medium-sized & -0.1673 & The Far Eastern & -0.3464 \\
cities & {$[0.1143]$} & region & {$[0.2238]$} \\
\hline Small towns & $-0.2233^{*}$ & Constant & $0.1958^{* *}$ \\
& {$[0.1302]$} & & {$[0.0894]$} \\
\hline The countryside & $-0.3325^{* *}$ & Number of & 250 \\
& {$[0.1328]$} & observations & \\
\hline The North & $0.2392^{*}$ & R-squared & 0.3062 \\
Western region & {$[0.1285]$} & & \\
\hline The Volga region & $-0.2500^{* *}$ & & \\
\hline & {$[0.1037]$} & & \\
\hline
\end{tabular}

The dependent variable is the individual mean of the children's residuals from equation (8) averaged over no less than 5 rounds of the survey.

${ }^{1}$ The individual mean of the parent's residuals from equation (8) averaged over no less than 5 rounds of the survey.

2 The reference group is capital cities including localities from the Moscow's region.

3 The reference group is the Central region.

* Significant at 0.1 level.

** Significant at 0.05 level.

$* * *$ Significant at 0.01 level.

Robust standard errors adjusted for 233 clusters in parents are in brackets. 
Table 8. The OLS estimates of equation (2).

\begin{tabular}{|c|c|c|c|}
\hline $\begin{array}{l}\text { Parent's } \\
\text { earnings }{ }^{1}\end{array}$ & $\begin{array}{c}0.2542^{* * *} \\
{[0.0610]}\end{array}$ & $\begin{array}{l}\text { Medium-sized } \\
\text { cities }\end{array}$ & $\begin{array}{l}-0.1375 \\
{[0.0948]}\end{array}$ \\
\hline $\begin{array}{c}\text { Parent's } \\
\text { technical school }^{2}\end{array}$ & $\begin{array}{c}0.0532 \\
{[0.0621]}\end{array}$ & Small towns & $\begin{array}{c}-0.1958^{*} \\
{[0.1081]}\end{array}$ \\
\hline $\begin{array}{c}\text { Tertiary } \\
\text { parent's } \\
\text { education }\end{array}$ & $\begin{array}{c}0.1236 \\
{[0.0904]}\end{array}$ & The countryside & $\begin{array}{c}-0.3607^{* * *} \\
{[0.1167]}\end{array}$ \\
\hline $\begin{array}{l}\text { More-paid (1) or } \\
\text { solely available } \\
(0) \text { parent is } \\
\text { selected }\end{array}$ & $\begin{array}{l}-0.0242 \\
{[0.0690]}\end{array}$ & $\begin{array}{l}\text { The North } \\
\text { Western region }^{5}\end{array}$ & $\begin{array}{c}0.2871^{* * *} \\
{[0.1072]}\end{array}$ \\
\hline Parent's gender & $\begin{array}{c}0.0278 \\
{[0.0641]}\end{array}$ & $\begin{array}{l}\text { The Volga } \\
\text { region }\end{array}$ & $\begin{array}{c}-0.2050^{* *} \\
{[0.0829]}\end{array}$ \\
\hline $\begin{array}{l}\text { Children's } \\
\text { technical school }^{2}\end{array}$ & $\begin{array}{c}0.1337^{* *} \\
{[0.0624]}\end{array}$ & $\begin{array}{l}\text { The Southern } \\
\text { region }\end{array}$ & $\begin{array}{c}0.0332 \\
{[0.1110]}\end{array}$ \\
\hline $\begin{array}{l}\text { Tertiary } \\
\text { children's } \\
\text { education }\end{array}$ & $\begin{array}{c}0.3004^{* * *} \\
{[0.0809]}\end{array}$ & $\begin{array}{c}\text { The North } \\
\text { Caucasian } \\
\text { region }\end{array}$ & $\begin{array}{l}-0.0945 \\
{[0.2375]}\end{array}$ \\
\hline $\begin{array}{l}\text { Children's } \\
\text { gender }\end{array}$ & $\begin{array}{c}0.3840 * * * \\
{[0.0563]}\end{array}$ & The Ural region & $\begin{array}{c}0.0440 \\
{[0.1203]}\end{array}$ \\
\hline $\begin{array}{c}\text { Children's } \\
\text { marital status }\end{array}$ & $\begin{array}{c}0.1156^{* *} \\
{[0.0543]}\end{array}$ & $\begin{array}{c}\text { The Siberian } \\
\text { region }\end{array}$ & $\begin{array}{l}-0.1861 \\
{[0.1146]} \\
\end{array}$ \\
\hline $\begin{array}{c}\text { Christian } \\
\text { (non-Russian) } \\
\text { children }^{3} \\
\end{array}$ & $\begin{array}{l}-0.0560 \\
{[0.2974]}\end{array}$ & $\begin{array}{c}\text { The Far Eastern } \\
\text { region }\end{array}$ & $\begin{array}{l}-0.2254 \\
{[0.2703]}\end{array}$ \\
\hline Moslem children & $\begin{array}{l}-0.0221 \\
{[0.1148]}\end{array}$ & Constant & $\begin{array}{c}-0.2856^{* *} \\
{[0.1107]}\end{array}$ \\
\hline $\begin{array}{l}\text { Children of } \\
\text { other } \\
\text { nationalities }\end{array}$ & $\begin{array}{c}0.0460 \\
{[0.1875]}\end{array}$ & $\begin{array}{l}\text { Number of } \\
\text { observations }\end{array}$ & 250 \\
\hline
\end{tabular}




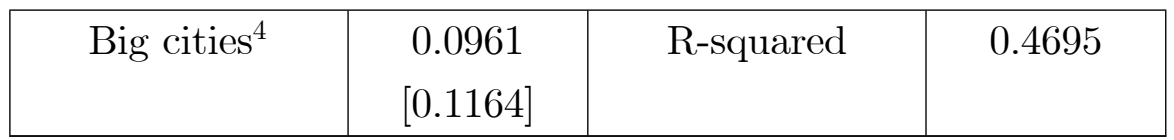

The dependent variable is the individual mean of the children's residuals from equation (8) averaged over no less than 5 rounds of the survey.

${ }^{1}$ The individual mean of the parent's residuals from equation (8) averaged over no less than 5 rounds of the survey.

2 The reference group is secondary education or less.

3 The reference group is Russian, Ukrainian, and Belorussian.

4 The reference group is capital cities including localities from the Moscow's region.

5 The reference group is the Central region.

* Significant at 0.1 level.

** Significant at 0.05 level.

*** Significant at 0.01 level.

Robust standard errors adjusted for 233 clusters in parents are in brackets. 
Table 9. The selected estimates of equation (2) by the quantile regression.

\begin{tabular}{|c|c|c|c|c|}
\hline & \multicolumn{4}{|c|}{ Quantiles } \\
\hline & 0.20 & 0.40 & 0.60 & 0.80 \\
\hline $\begin{array}{c}\text { Parent's } \\
\text { earnings }^{1}\end{array}$ & $0.3184^{* * *}$ & $0.2991^{* * *}$ & $0.2300^{* *}$ & $0.3823^{* * *}$ \\
{$[0.1048]$} & {$[0.0792]$} & {$[0.0891]$} & {$[0.0949]$} \\
\hline $\begin{array}{c}\text { Parent's } \\
\text { technical school }\end{array}$ & -0.0671 & -0.0182 & 0.0348 & 0.1055 \\
{$[0.1057]$} & {$[0.0907]$} & {$[0.0836]$} & {$[0.0951]$} \\
\hline $\begin{array}{c}\text { Tertiary } \\
\text { parent's } \\
\text { education }\end{array}$ & 0.0328 & 0.0546 & 0.0873 & -0.0089 \\
\hline 0.1583$]$ & {$[0.1282]$} & {$[0.1255]$} & {$[0.1205]$} \\
\hline $\begin{array}{c}\text { Children's } \\
\text { technical school }\end{array}$ & $0.2054^{* *}$ & $0.1617^{*}$ & $0.1755^{* *}$ & 0.1066 \\
\hline $\begin{array}{c}\text { Tertiary } \\
\text { children's } \\
\text { education }\end{array}$ & $0.3676^{* * *}$ & {$[0.0872]$} & {$[0.0893]$} & {$[0.1068]$} \\
\hline $\begin{array}{c}\text { Number of } \\
\text { observations }\end{array}$ & 250 & {$[0.1049]$} & $0.4027^{* * *}$ & $0.3447^{* * *}$ \\
\hline $\begin{array}{c}\text { Pseudo } \\
\text { R-squared }\end{array}$ & 0.3252 & $0.1038]$ & {$[0.1152]$} \\
\hline
\end{tabular}

The dependent variable is the individual mean of the children's residuals from equation (8) averaged over no less than 5 rounds of the survey.

${ }^{1}$ The individual mean of the parent's residuals from equation (8) averaged over no less than 5 rounds of the survey.

${ }^{2}$ The reference group is secondary education or less.

* Significant at 0.1 level.

** Significant at 0.05 level.

*** Significant at .01 level.

Bootstrap standard errors are in brackets. 
Table 10. The OLS estimates of equation (3).

\begin{tabular}{|c|c|c|c|}
\hline $\begin{array}{l}\text { Parent's technical } \\
\text { school }^{1}\end{array}$ & $\begin{array}{c}0.0067 \\
{[0.0395]}\end{array}$ & $\begin{array}{c}\text { The North } \\
\text { Western region }\end{array}$ & $\begin{array}{c}0.2799 * * * \\
{[0.0623]}\end{array}$ \\
\hline $\begin{array}{l}\text { Tertiary parent's } \\
\text { education }\end{array}$ & $\begin{array}{c}0.0691 \\
{[0.0504]}\end{array}$ & The Volga region & $\begin{array}{l}-0.0862 \\
{[0.0655]}\end{array}$ \\
\hline $\begin{array}{l}\text { More-paid (1) or } \\
\text { solely available }(0) \\
\text { parent is selected }\end{array}$ & $\begin{array}{c}0.0467 \\
{[0.0531]}\end{array}$ & $\begin{array}{c}\text { The Southern } \\
\text { region }\end{array}$ & $\begin{array}{c}0.0814 \\
{[0.0675]}\end{array}$ \\
\hline Parent's gender & $\begin{array}{c}0.0238 \\
{[0.0353]}\end{array}$ & $\begin{array}{c}\text { The North } \\
\text { Caucasian region }\end{array}$ & $\begin{array}{l}-0.0282 \\
{[0.0937]}\end{array}$ \\
\hline $\begin{array}{c}\text { Children's } \\
\text { technical school }^{1}\end{array}$ & $\begin{array}{c}0.1010^{* *} \\
{[0.0434]}\end{array}$ & The Ural region & $\begin{array}{l}0.1532^{*} \\
{[0.0928]}\end{array}$ \\
\hline $\begin{array}{l}\text { Tertiary children's } \\
\text { education }\end{array}$ & $\begin{array}{c}0.2947^{* * *} \\
{[0.0548]}\end{array}$ & $\begin{array}{l}\text { The Siberian } \\
\text { region }\end{array}$ & $\begin{array}{l}-0.0112 \\
{[0.0750]}\end{array}$ \\
\hline Children's gender & $\begin{array}{c}0.3445^{* * *} \\
{[0.0383]}\end{array}$ & $\begin{array}{c}\text { The Far Eastern } \\
\text { region }\end{array}$ & $\begin{array}{c}0.2477 \\
{[0.1705]}\end{array}$ \\
\hline $\begin{array}{c}\text { Children's marital } \\
\text { status }\end{array}$ & $\begin{array}{c}0.1091^{* * *} \\
{[0.0330]}\end{array}$ & $\begin{array}{c}\text { Children employed } \\
\text { as army } \\
\end{array}$ & $\begin{array}{c}0.0560 \\
{[0.1446]}\end{array}$ \\
\hline $\begin{array}{c}\text { Christian } \\
\text { (non-Russian) } \\
\text { children }^{2}\end{array}$ & $\begin{array}{c}0.0570 \\
{[0.1294]}\end{array}$ & $\begin{array}{c}\text { Children employed } \\
\text { as technicians }\end{array}$ & $\begin{array}{l}-0.0719 \\
{[0.0508]}\end{array}$ \\
\hline Moslem children & $\begin{array}{c}0.0699 \\
{[0.0772]}\end{array}$ & $\begin{array}{c}\text { Children employed } \\
\text { as clerks and } \\
\text { service workers }\end{array}$ & $\begin{array}{c}-0.1734^{* * *} \\
{[0.0567]}\end{array}$ \\
\hline $\begin{array}{c}\text { Children of other } \\
\text { nationalities }\end{array}$ & $\begin{array}{c}0.1150 \\
{[0.1552]}\end{array}$ & $\begin{array}{l}\text { Children employed } \\
\text { as craft and related } \\
\text { trades }\end{array}$ & $\begin{array}{l}-0.0672 \\
{[0.0720]}\end{array}$ \\
\hline Big cities $^{3}$ & $\begin{array}{l}-0.1088 \\
{[0.0791]}\end{array}$ & $\begin{array}{c}\text { Children employed } \\
\text { as machine } \\
\text { operators and } \\
\text { assemblers }\end{array}$ & $\begin{array}{l}-0.0856 \\
{[0.0690]}\end{array}$ \\
\hline
\end{tabular}




\begin{tabular}{|c|c|c|c|}
\hline $\begin{array}{c}\text { Medium-sized } \\
\text { cities }\end{array}$ & $\begin{array}{c}-0.2434^{* * *} \\
{[0.0540]}\end{array}$ & $\begin{array}{c}\text { Children employed } \\
\text { as skilled } \\
\text { agricultural, } \\
\text { fishery and } \\
\text { unskilled workers }\end{array}$ & $\begin{array}{c}-0.4002^{* * *} \\
{[0.0657]}\end{array}$ \\
\hline Small towns & $-0.3240^{* * *}$ & Constant & -0.0393 \\
{$[0.0741]$} & $0.0715]$ \\
\hline The countryside & $-0.6135^{* * *}$ & Number of & 733 \\
& {$[0.0660]$} & observations & R-squared \\
\hline & & & 0.4178 \\
\hline
\end{tabular}

The dependent variable is the individual mean of the children's residuals from equation (8) averaged over no less than 5 rounds of the survey.

1 The reference group is secondary education or less.

2 The reference group is Russian, Ukrainian, and Belorussian.

3 The reference group is capital cities including localities from the Moscow's region.

4 The reference group is the Central region.

5 The reference group is officials, managers, and professionals.

* Significant at 0.1 level.

** Significant at 0.05 level.

*** Significant at 0.01 level.

Robust standard errors adjusted for 681 clusters in parent are in brackets. 
Table 11. The estimates of the ordered probit model on the sample of sons and fathers (equation (4)).

\begin{tabular}{|c|c|c|c|}
\hline $\begin{array}{c}\text { Father's } \\
\text { technical school }^{1}\end{array}$ & $\begin{array}{c}0.5317^{* * *} \\
{[0.0929]}\end{array}$ & $\begin{array}{c}\text { The Siberian } \\
\text { region }\end{array}$ & $\begin{array}{c}-0.4054^{* * *} \\
{[0.1576]}\end{array}$ \\
\hline $\begin{array}{l}\text { Tertiary father's } \\
\text { education }\end{array}$ & $\begin{array}{c}0.9509 * * * \\
{[0.1428]}\end{array}$ & $\begin{array}{c}\text { The Far Eastern } \\
\text { region }\end{array}$ & $\begin{array}{l}-0.2954 \\
{[0.2141]}\end{array}$ \\
\hline $\begin{array}{l}\text { Son's marital } \\
\text { status }\end{array}$ & $\begin{array}{c}0.1511 \\
{[0.1009]}\end{array}$ & $\begin{array}{l}\text { Son born in } \\
1976-1980^{5}\end{array}$ & $\begin{array}{c}-0.3608^{* * *} \\
{[0.1220]}\end{array}$ \\
\hline $\begin{array}{c}\text { Christian } \\
\text { (non-Russian) } \\
\text { son }^{2}\end{array}$ & $\begin{array}{l}-0.2054 \\
{[0.1987]}\end{array}$ & $\begin{array}{c}\text { Son born in } \\
1971-1975\end{array}$ & $\begin{array}{c}-0.4684^{* * *} \\
{[0.1340]}\end{array}$ \\
\hline Moslem son & $\begin{array}{c}-0.4107^{* *} \\
{[0.2021]} \\
\end{array}$ & $\begin{array}{c}\text { Son born in } \\
1966-1970\end{array}$ & $\begin{array}{c}-0.3619^{* *} \\
{[0.1578]}\end{array}$ \\
\hline $\begin{array}{l}\text { Son of other } \\
\text { nationalities }\end{array}$ & $\begin{array}{c}0.5745^{* * *} \\
{[0.2150]}\end{array}$ & $\begin{array}{c}\text { Son born in } \\
1961-1965\end{array}$ & $\begin{array}{l}-0.2877 \\
{[0.1830]}\end{array}$ \\
\hline Big cities ${ }^{3}$ & $\begin{array}{c}0.3159 \\
{[0.2128]}\end{array}$ & $\begin{array}{c}\text { Son born in } \\
1956-1960\end{array}$ & $\begin{array}{l}-0.3053 \\
{[0.2369]}\end{array}$ \\
\hline $\begin{array}{l}\text { Medium-sized } \\
\text { cities }\end{array}$ & $\begin{array}{c}0.2581 \\
{[0.1723]}\end{array}$ & $\begin{array}{c}\text { Son born in } \\
1947-1955\end{array}$ & $\begin{array}{l}-0.5856 \\
{[0.3676]}\end{array}$ \\
\hline Small towns & $\begin{array}{c}0.0572 \\
{[0.1789]}\end{array}$ & $\begin{array}{c}\mathrm{N} \text { of members in } \\
\text { the son's } \\
\text { household }\end{array}$ & $\begin{array}{l}-0.0358 \\
{[0.0294]}\end{array}$ \\
\hline The countryside & $\begin{array}{l}-0.2301 \\
{[0.1719]}\end{array}$ & $\begin{array}{c}\mathrm{N} \text { of children } \\
\text { aged under } 3 \text { in } \\
\text { the son's } \\
\text { household }\end{array}$ & $\begin{array}{l}-0.0472 \\
{[0.1499]}\end{array}$ \\
\hline $\begin{array}{c}\text { The North } \\
\text { Western region }{ }^{4}\end{array}$ & $\begin{array}{l}-0.2610 \\
{[0.1750]}\end{array}$ & $\begin{array}{l}\mathrm{N} \text { of children } \\
\text { aged under } 17 \\
\text { in the son's } \\
\text { household }\end{array}$ & $\begin{array}{c}0.1139 \\
{[0.0808]}\end{array}$ \\
\hline $\begin{array}{l}\text { The Volga } \\
\text { region }\end{array}$ & $\begin{array}{c}-0.3926^{* * *} \\
{[0.1449]}\end{array}$ & Cutpoint 1 & $\begin{array}{l}-0.5206 \\
{[0.2234]}\end{array}$ \\
\hline
\end{tabular}




\begin{tabular}{|c|c|c|c|}
\hline $\begin{array}{c}\text { The Southern } \\
\text { region }\end{array}$ & $\begin{array}{c}0.0187 \\
{[0.1545]}\end{array}$ & $\begin{array}{c}\text { Cutpoint } 2 \\
{[0.2228]}\end{array}$ \\
\hline $\begin{array}{c}\text { The North } \\
\text { Caucasian } \\
\text { region }\end{array}$ & $\begin{array}{c}0.1750 \\
{[0.2209]}\end{array}$ & $\begin{array}{c}\text { Number of } \\
\text { observations }\end{array}$ & 848 \\
\hline The Ural region & $\begin{array}{c}-0.5818^{* * *} \\
{[0.2015]}\end{array}$ & $\begin{array}{c}\text { Pseudo } \\
\text { R-squared }\end{array}$ & 0.0925 \\
\hline
\end{tabular}

The dependent variable is the 3-level categorical variable of son's education attainment.

1 The reference group is secondary education or less.

2 The reference group is Russian, Ukrainian, or Belorussian.

3 The reference group is capital cities excluding localities from the Moscow's region.

4 The reference group is the Central region.

5 The reference group is sons born in 1981-83 years.

** Significant at .05 level.

$* * *$ Significant at .01 level.

Robust standard errors adjusted for 742 clusters formed by father are in brackets. 
Table 12. The estimates of the ordered probit model on the sample of daughters and fathers (equation (4)).

\begin{tabular}{|c|c|c|c|}
\hline $\begin{array}{c}\text { Father's } \\
\text { technical school }^{1}\end{array}$ & $\begin{array}{c}0.4873^{* * *} \\
{[0.0962]}\end{array}$ & $\begin{array}{c}\text { The Siberian } \\
\text { region }\end{array}$ & $\begin{array}{c}-0.4364^{* *} \\
{[0.1795]}\end{array}$ \\
\hline $\begin{array}{c}\text { Tertiary father's } \\
\text { education }\end{array}$ & $\begin{array}{c}0.9672^{* * *} \\
{[0.1390]}\end{array}$ & $\begin{array}{c}\text { The Far Eastern } \\
\text { region }\end{array}$ & $\begin{array}{l}-0.3046 \\
{[0.2099]}\end{array}$ \\
\hline $\begin{array}{c}\text { Daughter's } \\
\text { marital status }\end{array}$ & $\begin{array}{c}0.1092 \\
{[0.0972]}\end{array}$ & $\begin{array}{l}\text { Daughter born } \\
\text { in } 1976-1980^{5}\end{array}$ & $\begin{array}{c}-0.2439 * * \\
{[0.1196]}\end{array}$ \\
\hline $\begin{array}{c}\text { Christian } \\
\text { (non-Russian) } \\
\text { daughter }^{2}\end{array}$ & $\begin{array}{l}0.4711^{*} \\
{[0.2687]}\end{array}$ & $\begin{array}{c}\text { Daughter born } \\
\text { in 1971-1975 }\end{array}$ & $\begin{array}{c}-0.3474^{* * *} \\
{[0.1288]}\end{array}$ \\
\hline $\begin{array}{c}\text { Moslem } \\
\text { daughter }\end{array}$ & $\begin{array}{l}-0.3246^{*} \\
{[0.1748]}\end{array}$ & $\begin{array}{c}\text { Daughter born } \\
\text { in } 1966-1970\end{array}$ & $\begin{array}{l}-0.2689^{*} \\
{[0.1493]}\end{array}$ \\
\hline $\begin{array}{l}\text { Daughter of } \\
\text { other } \\
\text { nationalities }\end{array}$ & $\begin{array}{l}-0.1919 \\
{[0.2725]}\end{array}$ & $\begin{array}{c}\text { Daughter born } \\
\text { in 1961-1965 }\end{array}$ & $\begin{array}{l}-0.1971 \\
{[0.1749]}\end{array}$ \\
\hline Big cities ${ }^{3}$ & $\begin{array}{c}0.2504 \\
{[0.2155]}\end{array}$ & $\begin{array}{c}\text { Daughter born } \\
\text { in } 1956-1960\end{array}$ & $\begin{array}{c}0.0527 \\
{[0.2891]}\end{array}$ \\
\hline $\begin{array}{c}\text { Medium-sized } \\
\text { cities }\end{array}$ & $\begin{array}{l}-0.2014 \\
{[0.1717]}\end{array}$ & $\begin{array}{c}\text { Daughter born } \\
\text { in } 1947-1955\end{array}$ & $\begin{array}{c}-0.5885^{* *} \\
{[0.2826]}\end{array}$ \\
\hline Small towns & $\begin{array}{l}-0.3303^{*} \\
{[0.1974]}\end{array}$ & $\begin{array}{c}\mathrm{N} \text { of members in } \\
\text { the daughter's } \\
\text { household }\end{array}$ & $\begin{array}{c}-0.0908^{* * *} \\
{[0.0306]}\end{array}$ \\
\hline The countryside & $\begin{array}{c}-0.6167^{* * *} \\
{[0.1744]}\end{array}$ & $\begin{array}{c}\mathrm{N} \text { of children } \\
\text { aged under } 3 \text { in } \\
\text { the daughter's } \\
\text { household }\end{array}$ & $\begin{array}{l}0.2438^{*} \\
{[0.1311]}\end{array}$ \\
\hline $\begin{array}{c}\text { The North } \\
\text { Western region }\end{array}$ & $\begin{array}{l}-0.2224 \\
{[0.1718]}\end{array}$ & $\begin{array}{l}\mathrm{N} \text { of children } \\
\text { aged under } 17 \text { in } \\
\text { the daughter's } \\
\text { household }\end{array}$ & $\begin{array}{l}-0.0769 \\
{[0.0718]}\end{array}$ \\
\hline
\end{tabular}




\begin{tabular}{|c|c|c|c|}
\hline $\begin{array}{c}\text { The Volga } \\
\text { region }\end{array}$ & $\begin{array}{c}-0.2137 \\
{[0.1462]}\end{array}$ & Cutpoint 1 & $\begin{array}{c}-1.5702 \\
{[0.2180]}\end{array}$ \\
\hline $\begin{array}{c}\text { The Southern } \\
\text { region }\end{array}$ & $\begin{array}{c}0.1521 \\
{[0.1580]}\end{array}$ & Cutpoint 2 & $\begin{array}{l}-0.3243 \\
{[0.2123]}\end{array}$ \\
\hline The North & -0.2400 & Number of & 803 \\
Caucasian & {$[0.2355]$} & observations & \\
region & & & \\
\hline The Ural region & $-0.5359^{* * *}$ & Pseudo & 0.1124 \\
& {$[0.1822]$} & R-squared & \\
\hline
\end{tabular}

The dependent variable is the 3-level categorical variable of daughter's education attainment.

1 The reference group is secondary education or less.

2 The reference group is Russian, Ukrainian, or Belorussian.

3 The reference group is capital cities excluding localities from the Moscow's region.

4 The reference group is the Central region.

5 The reference group is daughters born in 1981-83 years.

* Significant at .10 level.

** Significant at .05 level.

*** Significant at .01 level.

Robust standard errors adjusted for 734 clusters formed by father are in brackets. 
Table 13. The selected estimates of the ordered probit model on the data on son-father and daughter-father pairs (equation (5)).

\begin{tabular}{|c|c|c|}
\hline & $\begin{array}{c}\text { Son-father } \\
\text { pairs }\end{array}$ & $\begin{array}{c}\text { Daughter- } \\
\text { father } \\
\text { pairs }\end{array}$ \\
\hline Father's $^{\text {earnings }}{ }^{1}$ & $\begin{array}{c}-0.0335 \\
{[0.1588]}\end{array}$ & $\begin{array}{c}0.0968 \\
{[0.1872]}\end{array}$ \\
\hline Father's $_{\text {technical school }}^{2}$ & $0.5859^{* * *}$ & $0.7605^{* * *}$ \\
{$[0.1678]$} & {$[0.2046]$} \\
\hline Tertiary father's $^{*}$ & $0.7932^{* * *}$ & $1.4000^{* * *}$ \\
education & {$[0.2719]$} & {$[0.2865]$} \\
\hline Cutpoint 1 $\left.^{*}\right]$ & -1.0879 & -2.3689 \\
{$[0.3941]$} & {$[0.5290]$} \\
\hline Cutpoint 2 & 0.1984 & -1.0611 \\
& {$[0.3949]$} & {$[0.5017]$} \\
\hline Number of & 240 & 239 \\
observations & & \\
\hline Pseudo & 0.1438 & 0.1817 \\
R-squared & & \\
\hline
\end{tabular}

The dependent variable is the 3-level categorical variable of children's education attainment.

1 The individual mean of the predicted father's residuals from equation (8) averaged over no less than 5 rounds of the survey.

2 The reference group is secondary education or less.

*** Significant at .01 level.

Robust standard errors are in brackets. The standard errors estimated on the son-father data are adjusted for 206 clusters formed by father. The standard errors estimated on the daughter-father data are adjusted for 207 clusters formed by father. 